SAND77-0369

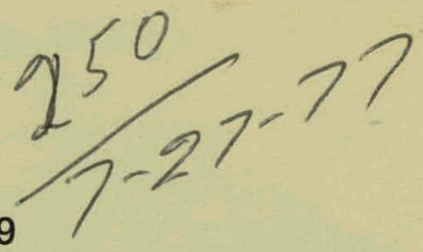

DP1258

Unlimited Release

UC-70

\title{
Neutron and Gamma-Ray Sources In LWR High-Level Nuclear Waste
}

Stephen A. Dupree

Prepared by Sandia Laboratories, Albuquerque New Mexico 87115

and Livermore, California 94550 for the United States Energy Research

and Development Administration under Contract AT (29-1)-789

Printed June 1977

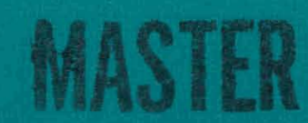

Sandia Laboratories 


\section{DISCLAIMER}

This report was prepared as an account of work sponsored by an agency of the United States Government. Neither the United States Government nor any agency Thereof, nor any of their employees, makes any warranty, express or implied, or assumes any legal liability or responsibility for the accuracy, completeness, or usefulness of any information, apparatus, product, or process disclosed, or represents that its use would not infringe privately owned rights. Reference herein to any specific commercial product, process, or service by trade name, trademark, manufacturer, or otherwise does not necessarily constitute or imply its endorsement, recommendation, or favoring by the United States Government or any agency thereof. The views and opinions of authors expressed herein do not necessarily state or reflect those of the United States Government or any agency thereof. 


\section{DISCLAIMER}

Portions of this document may be illegible in electronic image products. Images are produced from the best available original document. 
Issued by Sandia Laboratories, operated for the United States Energy Research \& Development Administration by Sandia Corporation.

\section{NOTICE}

This report was prepared as an account of work sponsored by the United States Government. Neither the United States nor the United States Energy Research \& Development Administration, nor any of their employees, nor any of their contractors, subcontractors, or their employees, makes any warranty, express or implied, or assumes any legal liability or responsibility for the accuracy, completeness or usefulness of any information, apparatus, product or process disclosed, or represents that its use would not infringe privately owned rights.

Printed in the United States of America

Available from

National Technical Information Service

U. S. Department of Commerce

5285 Port Royal Road

Springfield, VA 22161

Price: Printed Copy $\$ 3.50$; Microfiche $\$ 3.00$ 


\section{PAGES 1 to 2 WERE INTENTIONALLY LEFT BLANK}


SAND77-0369

Unlimited Release .

Printed June 1977
Distribution

Category UC-70

NEUTRON AND GAMMA-RAY SOURCES IN LWR HIGH-LEVEL NUCLEAR WASTE

Stephen A. Dupree

Theoretical Division, 5231

Sandia Laboratories

Albuquerque, NM 87115

\section{ABSTRACT}

Predictions of the composition of high-level waste from $\mathrm{U}$-fueled LWRs have been used to calculate the neutron and gamma-ray sources in such waste at cooling times of 3 and 10 years. The results are intended for interim application to studies of waste shipping and storage pending the availability of more exact knowledge of fuel recycling and of waste concentration and solidification.

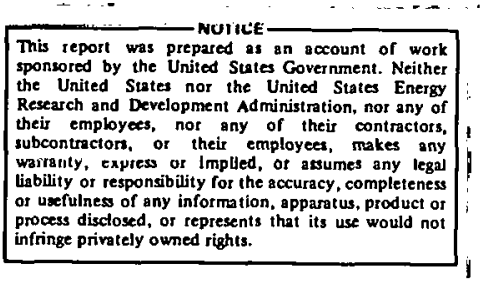




\section{CONTENTS}

$\begin{array}{lr}\text { Introduction } & \frac{\text { Page }}{7} \\ \text { Projected Composition of LWR High-Level Waste } & 7 \\ \text { Calculation of Source Strength } & 8 \\ \text { Conclusions } & 16 \\ \text { References } & 16\end{array}$

TABLES

Table

$\underline{\text { Page }}$

I Calculated Actinide Activities in High-Level Waste From $1 \mathrm{MT}$ of LWR U Fuel at 3- and 10-Year Decay Following Reprocessing

II Calculated Fission Product Activities in High-Level Waste From $1 \mathrm{MT}$ of LWR U Fuel at 3- and 10-Year Decay Following Reprocessing

III Calculated Fission Product Gamma-Ray Source Intensity per $\mathrm{cm}^{3}$ of Solidified LWR High-Level Waste at 3- and 10-Year Decay Following Reprocessing

IV Stynlilcant Contributing Fission Product Is otopes Ciáculated for Gamma-Ray Source Intensity in LWR High-Level Waste

V Calculated Actinide Gamma-Ray Source Intensity per $\mathrm{cm}^{3}$ of Solidified LWR High-Level Wastes at 3- and 10-Year Decay Following Reprocessing

VI Calculated Neutron Source Intensity per $\mathrm{cm}^{3}$ of Solidified LWR HighLevel Waøte at 3*and $10^{\circ}$-Year Decay Following Reprocessing 
NEUTRON AND GAMMA-RAY SOURCES

IN LWR HIGH-LEVEL NUCLEAR WASTE

Introduction

Expected intensities of neutron and gamma-ray sources present in high-level nuclear waste depend on the history and composition of the particular waste. Characteristics of the reactor in which the waste was generated, the extent to which recycle chemistry is performed on the waste, the degree of concentration or solidification of the residual material, and the cooling time before and after recycling - all contribute to the radiation source intensities in a specific piece of waste material. Any attempt to generalize the neutron and gamma-ray source strengths in high-level nuclear waste must therefore constitute a compromise of some sort.

The purpose of this report is to provide an interim source definition for high-level radioactive waste from light-water reactor ( $L W R$ ) fuel reprocessing. Pending the availability of more exact knowledge of fuel recycling and of waste concentration and solidification, the results should be useful to programs requiring such sources. The uncertainty in the results presented here although unknown - is certainly large, at least a factor of 2 .

Projected Composition of LWR High-Level Waste

High-level wastes are defined" as "those aqueous wastes resulting from the operation of the first cycle solvent extraction system, or equivalent, and the concentrated wastes from subsequent extraction cycles, or equivalent, in a facility for reprocessing irradiated reactor fuels." These wastes are presumed to contain virtually all the generated fission products, several tenths of a percent of the $\mathrm{U}$ and $\mathrm{Pu}$ originally present in the spent fuel, and all other actinides generated during the irradiation cycle. Regulations call for these wastes to be solidified within a period of 5 years from the time the liquid is generated (one of the first steps in the fuel recycling) and to be shipped to a government repository within 10 years from the time the liquid is generated.

The present study uses the results of an analysis by Blomeke et al. ${ }^{2}$ as a basis for defining the neutron and gamma-ray sources in LWR high-level wastes. The source data presented here. pertain only to U-fueled LWRs, ${ }^{*}$ and the fuel is assumed to be reprocessed following a 150-day postirradiation decay period.

*The Blomeke analysis assumed the initiation of $\mathrm{Pu}$ recycle in the LWR fuels for 1979. Although this date may now appear premature, the assumption of $\mathrm{Pu}$ recycle at some point in the future is cenlainity reascrinablit. 
Using models for the chemical treatment expected in spent-fuel recycling, including calcine and glassy product formation, Blomeke et al. predicted the volume of recycled waste, excluding cladding, to lie in the neighborhood of 1 to $2 \mathrm{ft}^{3}$ per metric ton (MT) of LWR fuel charged to the reactor. Despite the uncertainty regarding these numbers, when one considers the likelihood of some dilution of the fully irradiated material with waste from partially irradiated malfunctioning fuel assemblies, equipment decontaminations, and other relatively low-intensity sources, the upperlimit volume of $2 \mathrm{ft}^{3}$ of solidified high-level waste per metric ton is believed to be the most realistic number now available.*

All tritium and noble-gas fission products, as well as 99.9 percent of the I and $\mathrm{Br}$ fission products, are assumed to be removed from the waste during the initial repronessing steps and, accordingly, are omitted from consideration in the source definition. The residue of $U$ and $P u$ in the final solidified waste is assumed to be 0.5 percent of that initially present in the spent fuel. No cladding or structural material is assumed to be present in the end-product solidified waste.

The LWR fuel is assumed to be enriched to 3.34 percent in ${ }^{235} \mathrm{U}$. The powcr level is assumed to be $30 \mathrm{MW} / \mathrm{MT}$, with a total burnup of $33 \mathrm{MWd} / \mathrm{kg}$ of heavy metal. The average neutron flux seen by the fuel during the irradiation period was $2.92 \times 10^{13} \mathrm{n} / \mathrm{cm}^{2} \cdot \mathrm{s}$. The actinide and the fission product compositions of waste from $1 \mathrm{MT}$ of LWR fuel ${ }^{1}$ derived from these assumptions are shown in Tables I and II.

It should be pointed out that some familiar isotopes are omitted from these tables because they do not contribute significantly to the radiation source in the waste material in the time frame of interest here.

\section{Calculation of Source Strength}

Given the isotopic composition of the waste material of interest, calculation of the gammaray source strength is straightforward insofar as the nuclear energy levels and cascade schemes - of the pertinent nuclei are known. Determination of the neutron source strength from spontaneous fission is likewise straightforward; however, certain assumptions must be made to obtain an estimate of the neutron source from charged-particle reactions.

For present purposes the gamma emission rates for the various isotopes of Tables I and II were taken from the ORIGEN library. ${ }^{4}$ This library was assembled by the Oak Ridge National Laboratory as a data base for the ORIGEN code. The isotope decay schemes in the liviary are taken from Lederer et al. 5 Bremsstrahlung is included by assuming $\mathrm{UO}_{2}$ as the matrix in which $\beta$-decay uccurs.

\footnotetext{
"In an update to Reference 1, Kee et al. ${ }^{3}$ revised the estimate for the volume of waste from $1 \mathrm{MT}$ of fuel charged to the reactor to 1 to $3 \mathrm{ft}^{3}$, with the upper limit as the recommended value. This, along with revisions in their actinide inventory, indicates that the present neutron results are conservative by approximately a factor of 2 , whereas the present gamma-ray results are conservative by approximately 50 percent (both on a per $\mathrm{cm}^{3}$ basis).
} 
TABLE I

Calculated Actinide Activities in High-Level Waste From $1 \mathrm{MT}$ of LWR U Fuel at 3- and 10-Year Decay Following Reprocessing ${ }^{\text {a }}$

Activity (Ci)

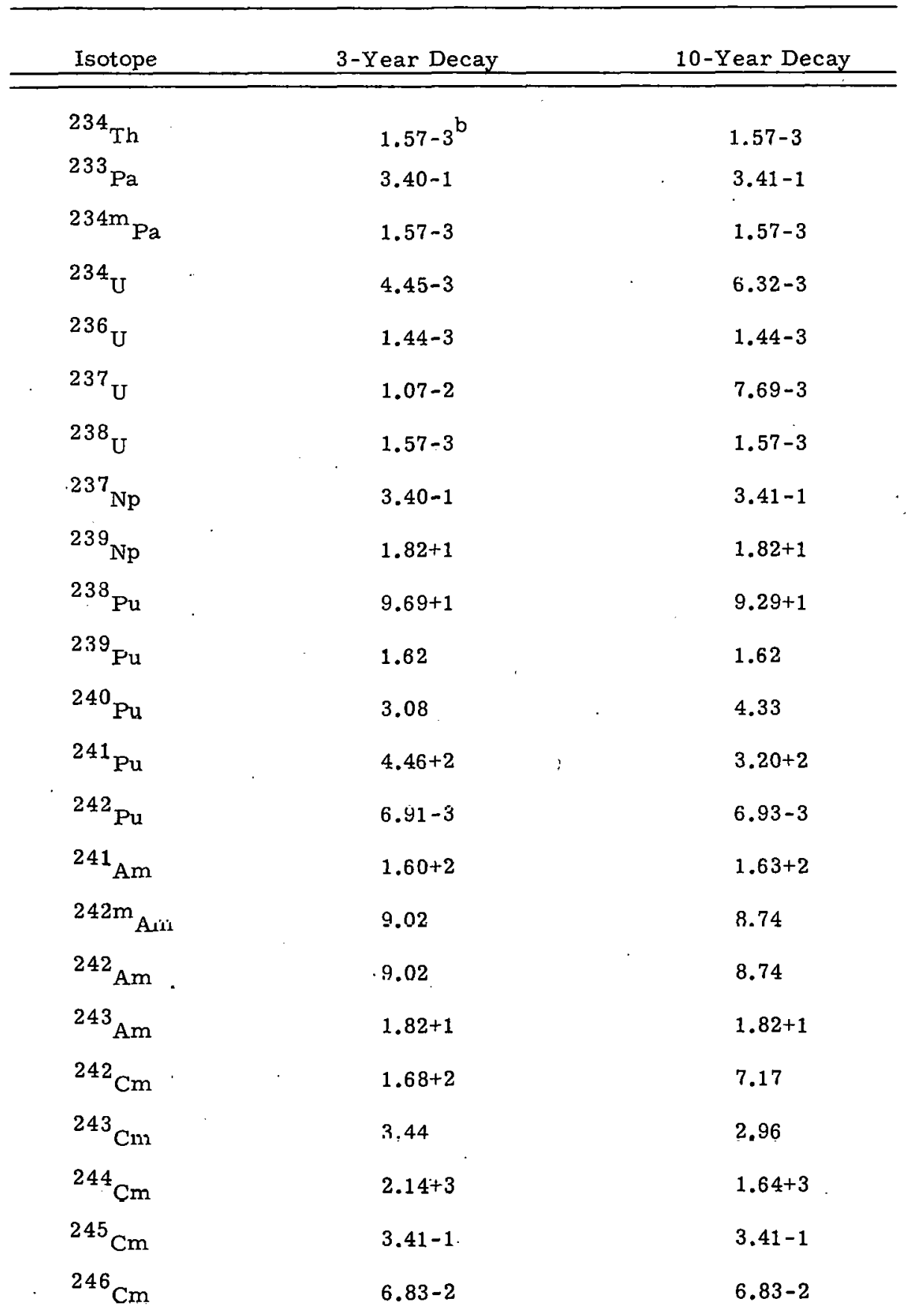

\footnotetext{
${ }^{a}$ Reprocessing is assumed to take place 150 days after completion of the fuel irradiation periud.

${ }^{b}$ Read 1.57-3, for example, as $1.57 \times 10^{-3}$.
} 
TABLE II

Calculated Fission Product Activities in High-Level Waste From $1 \mathrm{MT}$ of LWR U Fuel at 3- and 10-Year Decay Following Reprocessing ${ }^{\mathrm{a}}$

\begin{tabular}{|c|c|c|}
\hline \multicolumn{3}{|c|}{ Activity (Ci) } \\
\hline Isotope & 3-Year Decay & 10-Year Decay \\
\hline${ }^{79} \mathrm{Se}$ & $3.98-1$ & $3.98-1$ \\
\hline${ }^{90} \mathrm{Sr}$ & $7.13+4$ & $6.00+4$ \\
\hline${ }^{90} \mathrm{Y}$ & $7.13+4$ & $6.00+4$ \\
\hline${ }^{93} \mathrm{Zr}$ & 1.89 & 1.89 \\
\hline $93 \mathrm{~m}_{\mathrm{Nb}}$ & $4.25-1$ & ห. $63-1$ \\
\hline${ }^{w} \mathrm{Tc}$ & $1.43+1$ & $1.43+1$ \\
\hline${ }^{106} \mathrm{Ru}$ & $5.08+4$ & $4.06+2$ \\
\hline${ }^{106} \mathrm{Rh}$ & $5.08+4$ & $1.06 \cdot 1.3$ \\
\hline${ }^{107} \mathrm{Pd}$ & $1.10-1$ & $1.10-1$ \\
\hline${ }^{110 m} \mathrm{Ag}$ & $1.18+2$ & $1.07-1$ \\
\hline${ }^{110} \mathrm{Ag}$ & $1.53+1$ & $1.39-2$ \\
\hline${ }^{113 \mathrm{~m} 1 \mathrm{Cd}}$ & 8.86 & 6.26 \\
\hline $125_{\mathrm{Sb}}$ & $3.65+3$ & $6.06+2$ \\
\hline $12.5 \mathrm{~m} / \mathrm{Ie}$ & $1.51+3$ & $2.51+2$ \\
\hline${ }^{126} \mathrm{Sn}$ & $5.46-1$ & $5.46-1$ \\
\hline $126 \mathrm{~m}_{\mathrm{Sb}}$ & $5.46-1$ & $5.46-1$ \\
\hline $126_{\mathrm{Sb}}^{\mathrm{S}}$ & $5.41-1$ & $5.41-1$ \\
\hline${ }^{134} \mathrm{Cs}$ & $7.70+4$ & 7. $22+3$ \\
\hline${ }^{135} \mathrm{Cs}$ & $2.86-1$ & 2. $86-1$ \\
\hline${ }^{137} \mathrm{Co}$ & $9.90+4$ & $8.47+4$ \\
\hline $137 \mathrm{~m}_{\mathrm{Ba}}$ & $9.31+4$ & 7. $83+1$ \\
\hline${ }^{144} \mathrm{Ce}$ & $5.19+4$ & $1,01+2$ \\
\hline${ }^{144} \mathrm{Fr}$ & $5.19+4$ & $1.01+2$ \\
\hline${ }^{147} \mathrm{Pm}$ & $1.10 \cdot 1$ & $8.90+3$ \\
\hline${ }^{151} \mathrm{Sm}$ & $1.22+3$ & $1.15+3$ \\
\hline $152 \mathrm{Eu}$ & $1.03+1$ & 6.86 \\
\hline${ }^{154} \mathrm{Eu}$ & $6.02+3$ & $4.15+3$ \\
\hline${ }^{155_{\mathrm{Eu}} \mathrm{u}}$ & $2.01+3$ & $1.37+2$ \\
\hline
\end{tabular}

Reprocessing is assumed to take place 150 days after completion of the fuel irradiation period. 
Because the matrix of the waste material is expected to be borosilicate glass or other low $-\mathrm{Z}$ material, this assumption produces a conservative overestimate of the gamma-ray source strength at energies below approximately $1 \mathrm{MeV}$. The gamma source library also includes photon emission from the ${ }^{18} \mathrm{O}(\alpha, \mathrm{n})^{21} \mathrm{~N}$ reaction, which is a significant source of neutrons in some types of spent fuel.

The total fission product gamma-ray source calculated for high-level LWR waste at 3 and 10 years after reprocessing is given in Table III. The source is normalized to $1 \mathrm{~cm}^{3}$ of solidified waste, with an assumption of $2 \mathrm{ft}^{3}$ of waste per metric ton of fuel charged to the reactor. The major contributors to the source in each energy group in the time frame of interest are shown in Table IV. It is apparent that a preponderance of the gamma source is contributed by a very few fission product isotopes over this time period. For a more extensive presentation ${ }^{6}$ of the isotopes important to gamma production in high-level waste as a function of time, see Figure 8 of Cohen."

TABLE III

Calculated Fission Product Gamma-Ray Source Intensity per $\mathrm{cm}^{3}$ of Solidified LWR High-Level Waste at 3- and 10-Year Decay Following Reprocessing ${ }^{a}$

\begin{tabular}{ccccc}
\hline $\begin{array}{l}\text { Energy } \\
\text { Group } b\end{array}$ & $\begin{array}{l}\text { Upper } \\
\text { Energy } \\
\text { Bound (MeV) }\end{array}$ & $\begin{array}{c}\text { Group Average } \\
\text { Energy (MeV) }\end{array}$ & Photons $/ \mathrm{cm}^{3} \cdot$ s Emitted in Group \\
\hline & & & $3-$ Year Decay & $10-$ Year Decay \\
\hline 5 & 3.5 & 3.25 & $1.4+5$ & $1.1+3$ \\
6 & 3.0 & 2.75 & $4.4+6$ & $3.6+4$ \\
7 & 2.6 & 2.38 & $5.6+7$ & $4.5+5$ \\
8 & 2.2 & 1.99 & $3.6+8$ & $1.7+6$ \\
9 & 1.8 & 1.55 & $1.9+9$ & $1.6+8$ \\
10 & 1.35 & 1.10 & $6.5+9$ & $2.3+9$ \\
11 & 0.9 & 0.63 & $2.0+11$ & $6.8+10$ \\
12 & 0.4 & 0.30 & $1.5+10$ & $3.0+9$ \\
\hline
\end{tabular}

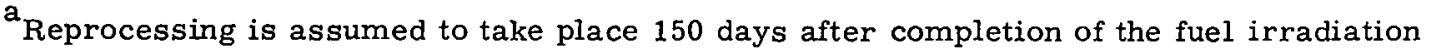
period.

${ }^{b}$ Fission product gamma source in Groups 1-4 is zero (see Table V for energy structure).

\footnotetext{
* Coher apparently used the same assumptions as Blomeke et al.
} 
TABLE IV

Significant Contributing Fission Product Isotopes Calculated for Gamma-Ray Source Intensity in LWR High-Level Waste ${ }^{2}$

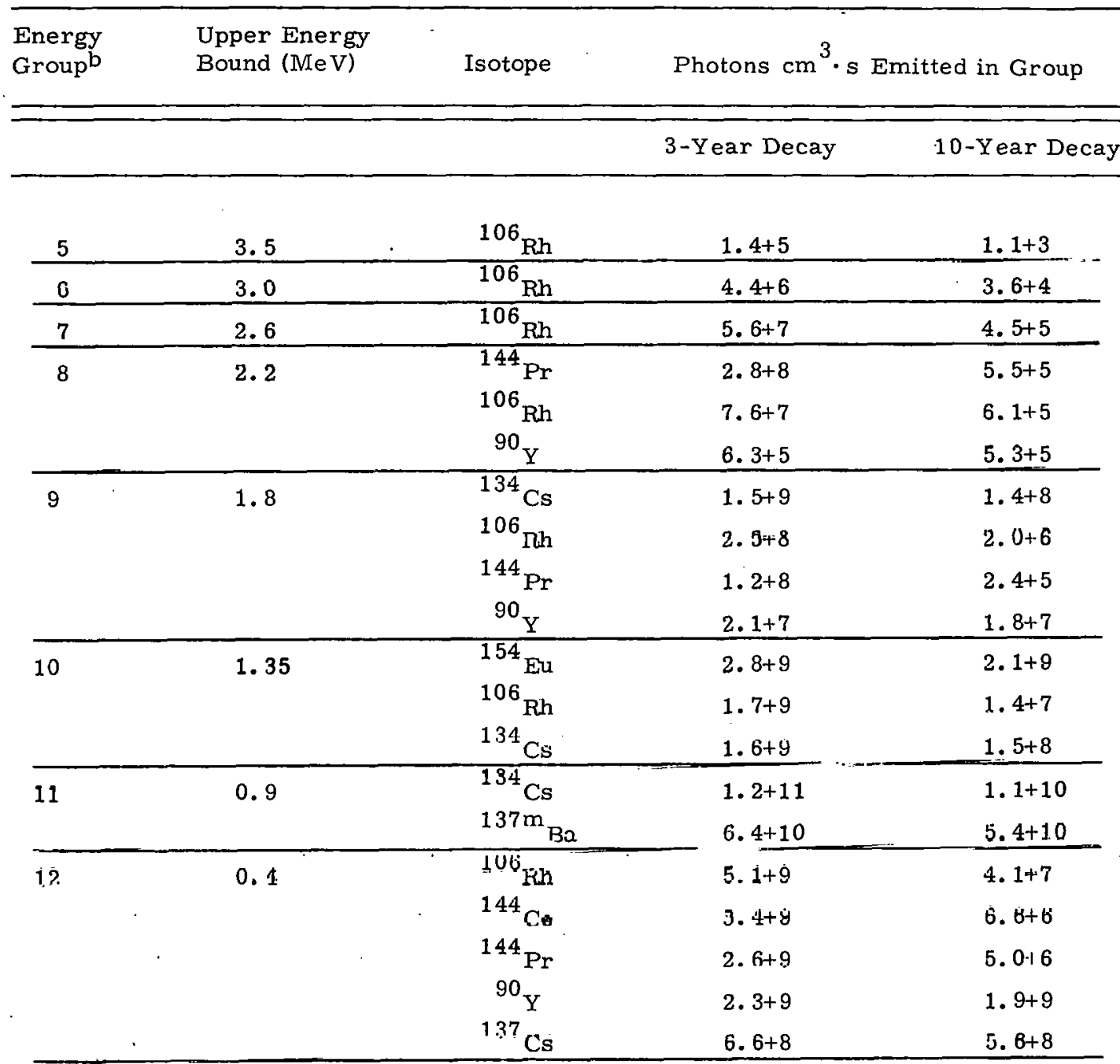

${ }^{a}$ Reprocessing is assumed to take place 150 days after completion of the fuel irradiation period.

${ }^{\mathrm{b}}$ Fission product gamma source in Groups 1-5 is zero.

Although the fission products contribute almost all of the gamma source in LWR high-level waste, the actinides are the source of some gamma radiation due to spontaneous fission and other minor reactions. The gamma-ray sources from the actinides, including daughter products, are given in Table V. Except for the fact that the actinides contribute the only gamma rays present above 3. $5 \mathrm{MeV}$ (Groups 1-4), their contribution to the total gamma-ray source is negligible and Table III may be considered to be the total gamma source. The actinide gamma source is shown here only for completenes. 
TABLE V

Calculated Actinide Gamma-ray Source Intensity per $\mathrm{cm}^{3}$ of Solidified LWR High-Level Wastes at 3- and 10-Year Decay Following Reprocessing ${ }^{2}$

\begin{tabular}{|c|c|c|c|c|}
\hline $\begin{array}{l}\text { Energy } \\
\text { Group }\end{array}$ & $\begin{array}{l}\text { Upper Energy } \\
\text { Bound ( } \mathrm{MeV} \text { ) }\end{array}$ & $\begin{array}{l}\text { Group Average } \\
\text { Energy (MeV) }\end{array}$ & Photons $/ \mathrm{cm}^{3} \cdot \mathrm{s}$ & Emitted in Group \\
\hline & & & 3-Year Decay & 10-Year Decay \\
\hline 1 & 5.5 & 5.25 & $2.2+1$ & $1.7+1$ \\
\hline 2 & 5.0 & 4.70 & $3.5+1$ & $2.7+1$ \\
\hline 3 & 4.5 & 4.22 & $7.4+1$ & $5.6+1$ \\
\hline 4 & 4.0 & 3.70 & $1.2+2$ & $8.9+1$ \\
\hline 5 & 3.5 & 3.25 & $1.8+2$ & $1.4+2$ \\
\hline 6 & 3.0 & 2.75 & $2.9+2$ & $2.2+2$ \\
\hline 7 & 2.6 & 2.38 & $6.3+2$ & $4.8+2$ \\
\hline 8 & 2.2 & 1.99 & $1.3+3$ & $9.6+2$ \\
\hline 9 & 1.8 & 1.55 & $2.4+3$ & $1.8+3$ \\
\hline 10 & 1.35 & 1.10 & $2.4+6$ & $2.4+6$ \\
\hline 11 & 0.9 & 0.63 & $9.6+6$ & $9.6+6$ \\
\hline 12 & $\begin{array}{l}0.4 \\
0.25^{b}\end{array}$ & 0.32 & $2.0+6$ & $2.0+6$ \\
\hline
\end{tabular}

${ }^{a}$ Reprocessing is assumed to take place 150 days after completion of the fuel irradiation period.

${ }^{b}$ Note that the lower bound of group 1.2 differs from that of Tables III and IV. Omitted from this table are $7.6 \times 10^{7}$ photons $/ \mathrm{cm}^{3} . \mathrm{s}$ emitted by the actinides at energies less than 250 . $\mathrm{keV}$.

Neutron production by the actinides predicted for J.WR. high-level waste at 3 and 10 years after reprocessing is shown in Table VI. Contributions of the $U$ and $\mathrm{Np}$ isotopes and of ${ }^{245} \mathrm{Cm}$, ${ }^{246} \mathrm{Cm}$, and ${ }^{239} \mathrm{Pu}$ to the total neutron production rate are insignificant in this time frame and therefore have been omitted from Table VI. Contributions due to spontaneous fission and $(\alpha, n)$ reactions are shown separately. The number of prompt neutrons emitted per spontaneous fission were taken from Devillers and Blum. ${ }^{7}$. The $(\alpha, \mathrm{n})$ reaction rate, taken from Bell, ${ }^{4}$ assumes.the presence of an oxide matrix for the ${ }^{18} \mathrm{O}(\alpha, n)^{21} \mathrm{~N}$. reaction in which half of the slowing down experienced by the alpha particles is due to the oxygen. For a more extensive presentation of the isotopes contributing to the neutron source as a function of time, see Figure 11 of Cohen. ${ }^{6}$ 
TABLE VI

Calculated Neutron Source Intensity per $\mathrm{cm}^{3}$ of Solidified LWR High-Level Waste at 3 - and 10-Year Decay Following Reprocessing ${ }^{a}$

\begin{tabular}{|c|c|c|c|c|}
\hline \multirow[t]{2}{*}{ Isotope } & \multicolumn{2}{|c|}{$\begin{array}{l}\text { Spontaneous Fission Neutron Production } \\
\text { Rate (neutrons } / \mathrm{cm}^{3} \cdot \mathrm{s}\end{array}$} & \multicolumn{2}{|c|}{$\begin{array}{l}{ }^{18} \mathrm{O}(\alpha, \mathrm{n})^{21} \mathrm{~N} \text { Neutron } \\
\text { Production Rate (neutrons/ } \\
\mathrm{cm}^{3} \cdot \mathrm{s} \text { ) }\end{array}$} \\
\hline & 3-Year Decay & 10-Year Decay & 3-Year Decay & 10-Year Decay \\
\hline \multirow{11}{*}{$\begin{array}{l}{ }^{238} \mathrm{Pu} \\
{ }^{240} \mathrm{Pu} \\
{ }^{241} \mathrm{Pu} \\
{ }^{241} \mathrm{Am} \\
{ }^{242 \mathrm{~m}_{\mathrm{Am}}} \\
{ }^{242} \mathrm{Am} \\
{ }^{243} \mathrm{Am} \\
{ }^{242} \mathrm{Cm} \\
{ }^{243} \mathrm{Cm} \\
{ }^{244} \mathrm{Cm}\end{array}$} & 2. 5-1 & $2.4-1$ & 1.6 & 1.5 \\
\hline & $2.1-1$ & 3. $0-1$ & 4. 1-2 & $5.7-2$ \\
\hline & 0 & 0 & 4.8 & 3.4 \\
\hline & 0 & 0 & 2.6 & 2.6 \\
\hline & b) & 0 & $1 \cdot 2-1$ & 1. $2-1$ \\
\hline & 0 & 0 & $1.2-1$ & 1. $2-1$ \\
\hline & 0 & 0 & $2.6-1$ & $2.6-1$ \\
\hline & 1. $7+1$ & $7 \cdot 4-1$ & 3.8 & $1.6-1$ \\
\hline & $\mathbf{0}$ & 0 & $6.7-2$ & $5.8-2$ \\
\hline & $5.1+3$ & $3.9+3$ & $4.2+1$ & $3.2+1$ \\
\hline & $5.1+3$ & $3.9+3$ & $5.5+\ddot{1}$ & $4.0+1$ \\
\hline
\end{tabular}

Total neutron production rate (neutrons $/ \mathrm{cm}^{3} \cdot \mathrm{s}$ )

$$
\begin{array}{rr}
\text { 3-year decay } & 5.2+3 \\
\text { 10-year decay } & 3.9+3
\end{array}
$$

${ }^{a}$ Reprocessing is assumed to take place 150 days after complction of the fuel irradiation period.

The energy spectrum of the neutrons from spontaneous fission is reasonably well known and, for practical purposes, can be assumed to be equal to a ${ }^{235} \mathrm{U}$ prompt fission neutron spectrum ( $\rho r e s e n t e d$ in numerous references). The neutrons produced by the $(\alpha, n)$ reactions are somewhat harder than an average prompt fission neutron. Their energies generally lie in the range of approximately 2 to $4 \mathrm{MeV}$; in the present case, however, because the $(\alpha, n)$ neutrono constitite only a small fraction of the total neutron source, it is safe to assume that all neutrons have a prompt fission neutron energy spectrum. From Table VI it is clear that ${ }^{244} \mathrm{Cm}$ may be cxpected to be the dominant source of neutrons in LWR high-level wastc at the cooling limes of interest.

Figures 8 and 11 of Reference 6 show the total gamma-ray power emitted and the neutrons/s emitted from all high-level nuclear waste generated in $400 \mathrm{GWe}$-years of operation of LWRs. In a fully developed nuclear power economy this amount of power is expected to be generated each ycar by nuclear reactor's. 
Current plans indicate that the high-level waste will be placed in metal canisters for transport to a permanent disposal site. Cohen's waste storage canister constitutes approximately $7.85 \mathrm{ft}^{3}$, or about $2.2 \times 10^{5} \mathrm{~cm}^{3}$, of solidified waste. Figure 11 of Reference 6 shows the neutron emission rate for each of these canisters. The $400 \mathrm{GWe}$-years of reactor operation is expected to generate approximately 4000 such canisters. Therefore, the present results can be compared directly with those of Cohen. Upon converting the gamma source of Table III to watts and scaling to 4000 canisters, one obtains $1.9 \times 10^{7}$ watts of gamma power at 3 years and $6.6 \times 10^{6}$ watts of gamma power at 10 years. Likewise, converting the neutron source of Table VI to neutrons per $7.85 \mathrm{ft}^{3}$ canister gives $1.2 \times 10^{9}$ neutrons/s at 3 years and $8.7 \times 10^{8}$ neutrons/s at 10 years. All these numbers are in good agreement with the results in Reference 6.

\section{Conclusions}

The LWR high-level waste radiation sources presented here are based on preliminary predictions of future light-water-reactor $U$ fuel reprocessing. As such, they are subject to large uncertainties and should be treated as estimates only. Nevertheless, it is hoped that they will be of use to the fuel-cycle community in studies of waste transport and storage.

Only results from 3 - and 10-year cooling time following reprocessing are presented. Because many different isotopes with widely divergent half-lives are present in the waste, it it improper to attempt to extrapolate to later times on the basis of the data presented here. Those interested in considering longer cooling times should see Figures 8 and 11 of Reference 6 , which provide data out to $10^{8}$ years after reprocessing. Gamma spectral changes should be significant over this period, with the average gamma energy decreasing markedly, whereas changes in the neutron energy spectrum should be small. However, the uncertainty in the total source strengths will increase with cooling time because, with time, the sources will depend increasingly on the precise mixture of the transuranic isotopes generated during the fuel-irradiation period and will depend decreasingly on the fission product mix. The former is known with significantly less accuracy than the lattor. 


\section{REFERENCES}

1. "Siting of Fuel Reprocessing Plants and Related Waste Management Facilities," Federal Register, 35, No. 222, 17530 (November 14, 1970).

2. J. O. Blomeke, C. W. Kee, and J. P. Nichols, Projections of Radioactive Wastes To Be Generated by the U. S. Nuclear Power Industry, ORNL-TM-3965, Oak Ridge National Laboratory, Oak Ridge, TN (February 1974).

3. C. W. Kcc, A. G. Ciuff, and J. O. Blomeke, Üpdated Predictions of Radioactive Wastes To Be Generated by the U, S, Nuclea.r Priurer Industry, ORNIL/TMI-542T, Uak Kidge National Laboratory, Oak Ridge, TN (December 1976).

4. M. J. Bell, ORIGEN - The ORNL Tsotope Generation and Depletion Code, ORNL 4628, Oak Ridge National Laboratory, Oak Ridge, TN (May 1973). The ORIGEN library is distributed along with the code as a code package $\mathrm{CCC}-217$ by the Radiation Shielding Information Center, Oak Ridge, TN.

5. C. M. Lederer, J. M. Hollander, and S. Pcrlman, Table of Isotopes (J. Wiley and Sons, New York, 1967).

6. Bernard L. Cohen, "High-Level Radioactive Waste from Light-Water Reactors," Rev Mod Phys, 49, 1 (1977).

7. C. Devillers and P. Blum, "Neutron Multiplication and Shielding Problems in PWR Spent-Fuel Shipping." Reprint of paper presented at ANS/ENS International Conference, Washington, D. C., November 14-19. 1976. Ahstrast publiohed in Tralls Am INuel SOC, 24, 401 (1976). 
DISTRIBUTION:

TID-4500-UC-70 (277)

Environmental Control Technology (3)

U. S. Energy Research and Development Administration Washington, D. C: 20545

Attn: W. A. Brobst

J. Counts

J. A. Sisler

U. S. Nuclear Regulatory Commission (6)

Washington, D. C. 20555

Attn: W. F. Anderson

C. R. Chappell

W. Lahs

C. B. MacDonald

D. A. Nussbaumer

R. C. Shieh

Battelle Pacific Northwest Laboratories (2)

P. O. Box 999

Richland, WA 99352

Attn: L. D. Williams

R. J. Hall

Battelle Columbus Laboratories (3)

505. King Avenue

Columbus, OH 43201

Attn: S. J. Basham

E. C. Lusk

R. A. Robinson

U. S. Energy Research and Development Administration (2)

Albuquerque Operations Office

Albuquerque, NM 87115

Attn: C. B. Quinn

J. $\Lambda$. Morley

Oak Ridge National Laboratory (2)

P. O. Box X

Oak Ridge, TN 37830

Attn: C. W. Kee

G. W. Morrison

Los Alamos Scientific Laboratory

Los Alamos, NM 87545

Attn: T. Butler,

Group WX-8

Lawrence Livermore Laboratory (2) P.O. Box 808

Livermore, CA 94550

Attn: F. J. Tokarz, MS L-90

R. T. Langland, MS L-90

Hanford Engineering Development Laboratory

P. O. Bnx 1970

Richland, WA 99352

Attn: C. L. Boyd, Mandger, Fuel Handling

P. D. Shaw 

Louviers Bldg.

Wilmington, DE 19898

Attn: J. Cherney

Engineering Department

E. I. DuPont de Nemours \& Co. Savannah River Plant

Aiken, SC 29081

Attn: J. W. Langhaar

Electric Power Research Institute (2)

P. O. Box 10412

Palo Alto, CA 94304

Attn: C. Chan

R, Ka, Winlstrilitioh

Monsanto Research Corporation Mound Laboratory

P. O. Box 32

Miduslsburg, UH 54342

Attn: D. Edling

Allied-General Nuclear Services

P. O. Rnx 847

Barnwell, SC 29812

Attn: R. W. Peterson

Bechtel Corporation

50 Beale Street

San Francisco, CA 94105

Attn: S. Golan

1140 W. D. Weart

1141 L. R. Hill

1141 J. P. Brannen

1141 M. M. Molecke

5413 J. E. C'ampbell

5430 R. M. Jefferson

1141 G. E. Barr

1142 L. W. Scully

1113 1'. D. OFBrien (3)

1233 J. M. Taylor

5000 A. Narath

5100 J. K. Galt

5200 E. H. Beckner

$5230 \mathrm{M}$. Cowan

5231 J. H. Renken

5231 S. A. Dupree (10)

b23' M. J. Forrestal

5400 A. W. Snyder

5410 D. J. MeClüskey

5431 W. A. Vun Reisemann

6433 R. B. Pope

5433 G. $\cap$ A llu

5433 J. M. Freedman (10)

5410 R. W. Lynch

5700 J. H. Scott

5800 R. S. Claassen

8266 E. A. Aas

3141 C. A. Pepmueller (5)

3151 W. L. Garner (3)

Pur: ERİA/'L'LC' (Unlimited Release) 